\title{
CZU:634.13:581.132 \\ https://doi.org/10.53040/gppb7.2021.27 \\ FITOMONITORIZAREA INTENSITĂŢII FOTOSINTEZEI, RESPIRAŢIEI ŞI TRANSPIRAŢIEI LA POMII DE PĂR
}

\author{
Şişcanu Gheorghe, Scurtu Gheorghe, Titova Nina \\ Institutul de Genetică, Fiziologie și Protecție a Plantelor, Chișinău, Republica Moldova \\ e-mail: nina.titova@igfpp.md
}

\begin{abstract}
The paper presents the results regarding the phytomonitoring of physiological processes in pear trees. The modern RTM-48A phytomonitor was used, which allowed the measurement of indices in the form of a film-phytodiagram that allows the diagnosis of the properties of genotype and physiological condition of plants. The light saturation curve for photosynthesis in pear plants was determined as a result of the evaluation of the intensity of photosynthesis, respiration, transpiration, stomata conductivity as a function of temperature, humidity and $\mathrm{CO} 2$ content in the air. The minimum value of light at which the photosynthesis process is initiated has been established. As the light intensity increases $(1 / 3$ of the total light) the intensity of photosynthesis increases after the essential optimization of the process has taken place.
\end{abstract}

Key words: pear trees, phytomonitoring, film- phytodiagram, photosynthesis, active photosynthetic radiation, respiration, transpiration, stomata conductivity.

\section{Introducere}

Productivitatea plantelor este determinată de activitatea unui complex de procese fiziologice şi biochimice, între care rolul principal aparţine fotosintezei [1] ce activează în legătură cu alte procese şi care în coordonare asigură viabilitatea organismului vegetal. De asemenea se cunoaşte că potenţialul de producţie la plante este determinat de genotip, însă realizarea lui în mare măsură depinde de factorii ecologici. Procesele fiziologice, inclusiv fotosinteza, permanent sunt supuse influenţei diferitor factori, cum ar fi lumina, temperatura, umiditatea, ceea ce influenţează asupra realizării productivităţii plantelor. Reieşind din aceste considerente paralel cu monitorizarea funcţionării proceselor fiziologice a fost înregistrată monitorizarea curbei de saturaţie a luminii pentru fotosinteză-element de performanţă, fotosinteza (brută şi netă), transpiraţia, respiraţia, conductivitatea stomatelor, temperatura, umiditatea, concentraţia de $\mathrm{CO}_{2}$. Experimental, în premieră, am efectuat cercetări de fitomonitorizare - 72 ore la plantele de păr.

Fitomonitorizarea a apărut istoric ca o secțiune instrumentală a biociberneticii vegetale în anii 50 ai secolului trecut $[2 ; 3 ; 4]$. Termenul fitomonitorizare însuși a fost propus în 1987 de oamenii de știință de la Laboratorul de Biocibernetică a Plantelor din Leningrad [3]. Dezvoltarea ulterioară a acestei direcții a dus la crearea unei metodologii de fitomonitorizare, care a fost proclamată ca o nouă metodologie a fiziologiei plantelor (fitomonitorizare fiziologică) [4]. Setul de înregistrări a parametrilor fiziologici (de regulă într-o zi sau mai mult) poate fi considerat ca o descriere a stării funcționale a unei plante aflate în cenoză sau ca semnale despre starea funcțională a plantei. Aceasta din urmă împrejurare vă permite să includem instalațiile în gestionarea procesului producțional pe principiul controlului feedback-ului. În prezent, fitomonitorizarea, ca o metodologie nouă a fiziologiei plantelor, a primit recunoaștere universală în Rusia, Australia, Israel, SUA, Chile, Republica Moldova și alte țări. Fitomonitorizarea în comun cu studiile fiziologice și biochimice este și diagnosticarea proprietăților genotipului a plantelor.

\section{Materiale şi metode}

În calitate de obiect de studiu a fost utilizat soiul tardiv de păr Noiabriscaya, specia Pyrus, familia Rozaceae în vârstă de 4 ani, cultivat în lizimetre. Soiul este răspândit în Republica Moldova şi ţările din spaţiul exsovietic sub numele de Noiabriscaya.

A fost utilizat fitomonitorul modern PTM-48A (Bioinstruments S.R.L) [5], care permite efectuarea măsurărilor sub formă de film-fitodiagramă la fiecare 15 minute, pe o durată de 72 ore, prin fitomonitorizare în regim automat. Fitomonitorul PTM-48A este compatibil cu drona de cercetare de marca "Phantom-2"[6] prin conexiuni directe şi prin programe proprii de colectare şi prelucrare a datelor. În rezultatul cercetărilor au fost înregistrate: fotosinteza- $\mu \mathrm{M} \mathrm{CO}_{2} \cdot \mathrm{m}^{-2} \cdot \mathrm{s}^{-1}$, asimilaţia reală- $\mu \mathrm{M} \mathrm{CO}_{2} \cdot \mathrm{m}^{-2} \cdot \mathrm{s}^{-1}$, respiraţia totală- $\mu \mathrm{M} \mathrm{CO}_{2} \cdot \mathrm{m}^{-}$ ${ }^{2} \cdot \mathrm{s}^{-1}$, faza de întuneric a respiraţiei- $\mu \mathrm{M} \mathrm{CO}_{2} \cdot \mathrm{m}^{-2} \cdot \mathrm{s}^{-1}$, fotorespiraţia- $\mu \mathrm{M} \mathrm{CO}_{2} \cdot \mathrm{m}^{-2} \cdot \mathrm{s}^{-1}$, transpiraţia $-\mathrm{mg} \mathrm{H}_{2} \mathrm{O} \cdot \mathrm{m}^{-}$ $2 \cdot \mathrm{s}^{-1}$, conductivitatea stomatelor $-\mathrm{gs}, \mathrm{mm} /{ }^{*} \mathrm{~s}$ a frunzelor intacte de păr. Prelucrarea rezultatelor măsurărilor permit obţinerea elementului fiziologic de performanţă: curba de saturaţie a luminii pentru fotosinteză $(\mu \mathrm{M}$ 
$\left.\mathrm{CO}_{2} \cdot \mathrm{m}^{-2} \cdot \mathrm{s}^{-1}\right)$, a fotosintezei brută şi netă $\left(\mu \mathrm{M} \mathrm{CO}_{2} \cdot \mathrm{m}^{-2} \cdot \mathrm{s}^{-1}\right)$. Prelucrarea statistică a datelor sa efectuat prin utilizarea aplicaţiilor software de calculator Statistica 10 (Stat soft INC, SUA) şi Microsoft Excel 2010. Pentru modelarea şi ajustarea datelor bidimensionale au fost utilizate metodele celor mai mici pătrate şi regresia puternic ponderată la nivel local. Toate calculele s-au efectuat la nivel de semnificaţie $\mathrm{P} \leq 0,05$.

\section{Rezultate şi discuţii}

Modalitatea principală de cercetare a fotosintezei, fie că a mecanismelor sau a proprietăţilor biologice, este bazată pe stabilirea legăturilor reciproce a fotosintezei cu alte procese metabolice a organismului vegetal. Prezenţa luminii, ca unul din factori exogeni, reprezintă principala condiţie pentru ca procesul de fotosinteză să activeze, ce şi a determinat studierea influenţei acestui factor asupra intensităţii fotosintezei prin acordarea unei mari atenţii, având la dispoziţie posibilităţile aparatului de monitorizare automată PTM-48A. Cercetările prezintă performanţa Curbele de saturaţie a luminii pentru fotosinteză la plantele de păr.

A fost stabilită intensitatea minimală a luminii la care începe procesul de fotosinteză. Fitomonitorul PTM48A are capacitatea de înregistrare a acestui minimum foarte mic. Odată cu creşterea intensităţii luminii (până la 1/3 din lumina solară totală) intensitatea fotosintezei se măreşte, după ce se micşorează majorarea fotosintezei în comparaţie cu intensitatea luminii. Cu creşterea în continuare a intensităţii luminii are loc procesul de saturaţie a fotosintezei. Majorarea în continuare a intensităţii luminii influenţează negativ asupra intensității procesului. Analizând datele constatăm, că la plantele de păr intensitatea fotosintezei începe să crească la apariţia luminii şi continuă până la iluminarea de $100-150 \mu \mathrm{M} \mathrm{CO}_{2} \cdot \mathrm{m}^{-2} \cdot \mathrm{s}^{-1}$, scade treptat până la $500 \mathrm{de} \mu \mathrm{M} \mathrm{CO}_{2} \cdot \mathrm{m}^{-2} \cdot \mathrm{s}^{-1}$, după ce se menţine la acelaşi nivel până la iluminarea de aproximativ de 1500 de $\mu \mathrm{M} \mathrm{CO}_{2}$, apoi creşte la $1800 \mu \mathrm{M}$. Baza energetică a fotosintezei este reprezentată de razele absorbite de clorofilă. Energia radiaţiei fotosintetice active reprezintă aproximativ 50\% din energia totală a radiaţiei solare. Partea infraroşie a spectrului solar, care reprezintă de asemenea aproximativ 50\% din energia totală a soarelui, nu participă la reacţiile fotochimice ale fotosintezei. Aceste raze sunt absorbite de sol - din care stratul de suprafaţă al aerului şi plantele însăşi sunt încălzite, iar transpiraţia şi evaporarea umidităţii din suprafaţa solului sunt îmbunătăţite. Un indicator obiectiv al productivității plantelor de cultură poate fi utilizarea radiației fotosintetice active (RFA). În procesul de fotosinteză nu participă toată energia solară, ci doar partea vizibilă cu lungimi de undă de la 380 la $720 \mathrm{~nm}$ (nanometri sau milimicroni). Randamentele bune corespund la 2-3\% utilizare a RFA. Acumularea de 3,5-5\% RFA şi mai mult este posibilă în recoltă. Efectul temperaturii asupra fotosintezei depinde de intensitatea iluminării. La o iluminare scăzută, fotosinteza nu depinde de temperatură. În condiţii de iluminare ridicată, intensitatea fotosintezei este determinată de activitatea reacţiilor ce se desfăşoare la faza de întuneric. Temperatura frunzei şi penetrarea frunzei de către lumină depinde de grosimea şi consistenţa acesteia. În frunze subţiri, capacitatea de căldură şi iluminare este scăzută şi reacţionează mai puternic la fluctuaţiile de iluminare. Când se determină intensitatea fotosintezei, se obţine magnitudinea fotosintezei observate (fotosinteza netă). Un indicator important al fotosintezei este intensitatea acesteia, adică cantitatea de $\mathrm{CO} 2$ absorbită pe unitatea de timp de o unitate a suprafeţei frunzelor. Pentru a obţine valoarea unei fotosinteze reale (fotosinteza brută), e necesar de adăugat o modificare a respiraţiei la fotosinteza observată. Astfel, materia organică acumulată de plante reprezintă diferenţa dintre substanţa organică formată în timpul fotosintezei şi substanţa folosită pentru respiraţie. Creşterea zilnică în greutate a materiei uscate pe unitatea de suprafaţă a unei plante se numeşte productivitate a fotosintezei. Intensitatea fotosintezei şi productivitatea fotosintetică la plantele diferitor specii, se deosebesc în mod esenţial.

Alimentarea cu carbon a unei frunze intacte la pomii de păr, prin absorbţia dioxidului de carbon din aer, combinată cu nutriţia azotului din sol, este principalul factor care asigură creşterea, randamentul ridicat şi rezistenţa la condiţiile ecologice. Fotosinteza este posibilă şi la temperaturile aerului frunzelor la care se opreşte creşterea plantelor. În acest caz, materia organică formată intră în stoc. Temperaturile deosebit de scăzute ale nopţii influențează negativ asupra transportului substanţelor plastice din frunze în alte organe ale plantelor. Activitatea aparatului fotosintetic şi fluxul de asimilare din frunze pot fi perturbate semnificativ când temperatura din zona rădăcinii scade. Limitele de temperatură în care este posibilă fotosinteza sunt deferă pentru diferitele plante. Scăderea temperaturii afectează în mod direct fotosinteza, reducând activitatea enzimelor implicate în reacţiile la întuneric. Temperatura minimă pentru fotosinteza plantelor este de aproximativ $0^{\circ} \mathrm{C}$. Temperatura optimă a fotosintezei pentru majoritatea plantelor este de aproximativ $20-25^{\circ} \mathrm{C}$. La temperaturi mai mari decât cele optime, intensitatea fotosintezei scade brusc. Astfel, creşterea temperaturii măreşte rata reacţiilor de întuneric a fotosintezei. În acelaşi timp, la o temperatură de $25-30^{\circ} \mathrm{C}$, are loc procesul de inactivare a cloroplastelor. Creşterea temperaturii poate cauza, de asemenea, oprirea fisurilor stomatelor. În cele din urmă, cum am menţionat deja, creşterea temperaturii stimulează 
intensitatea respiraţiei şi în acest sens scade fotosinteza vizibilă (diferenţa dintre fotosinteză şi respiraţie). Scăderea temperaturii reduce fotosinteza, deoarece activitatea enzimelor este inhibată, viteza proceselor de difuzie scade, precum şi fluxul de asimilate. Temperatura frunzei depinde de grosimea şi consistenţa acesteia. În frunze subţiri, capacitatea de căldură este scăzută ce reacţionează mai puternic la fluctuaţiile de iluminare.

Atmosfera, care reprezintă, în medie, sursa principală de $\mathrm{CO}_{2}$ pentru plante, conţine $0,03 \% \mathrm{CO}_{2}$ și creşterea concentraţiei de $\mathrm{CO}_{2}$ în aer de la 0,2 până la $0,6 \%$ accelerează procesul de fotosinteză; conduce la o creştere a randamentului plantelor cu $12-16 \%$. Când concentraţia de $\mathrm{CO}_{2}$ în aer este mai mare de $0,6 \%$, creşterea plantelor poate încetini

Transpiraţia reprezintă procesul de mişcare a apei prin plante şi evaporarea acesteia prin organele externe ale ei, cum ar fi frunzele, lăstarii şi florile. Apa este necesară pentru viaţa plantei, dar doar o mică parte din apa care intră prin rădăcini este folosită direct în procesele metabolice, însă restul se pierde prin transpiraţie.

Stomatele sunt limitate de celulele de închidere şi celulele însoţitoare (cunoscute colectiv ca complex de stomate), care deschid şi închid porii. Transpiraţia trece prin fisuri şi poate fi considerată un necesar asociat pentru accesul dioxidului de carbon pentru fotosinteză. Transpiraţia răceşte planta, modifică presiunea osmotică din celule şi asigură mişcarea apei şi a substanţelor nutritive. Conductibilitatea stomatelor confirmă performanţa - Curbelor de saturaţie a luminii pentru fotosinteză.

În anii 70 ai secolului trecut, problema gradului de saturaţie a vaporilor de apă într-o cavitate a fost subiectul unei discuţii. Până în prezent, prevederea privind saturarea completă a vaporilor de apă în cavitatea de sublimităţi e fixată în final în teoria schimbului de gaze fotosintetice. Echipamentele moderne de sensibilitate ridicată pentru calculul conductivităţii stomatelor în prelucrarea computerizată a indicatorilor fizici ai schimbului de gaze se bazează pe ipoteza de saturaţie completă a cavităţii sub convenţionale cu vapori de apă. Condensarea apei pe suprafaţa plantelor prin reducerea temperaturii suprafeţei frunzelor sub punctul de rouă, indiferent de mecanismul de răcire a frunzelor şi a lăstarilor, demonstrează că toate plantele pot condensa umiditatea atmosferică, în special în absenţa luminii a soarelui, cu condiţia ca punctul de rouă să se situeze în intervalul unei posibile scăderi a temperaturii $<10^{\circ} \mathrm{C}$. Respiraţia ocupă un loc important în rezolvarea problemei productivităţii plantelor. Un interes deosebit este evaluarea raportului cantitativ al respiraţiei şi fotosintezei. Astfel, respiraţia este strâns legată de toate procesele metabolice ale organismului şi este un proces fără de care viaţa este imposibilă. Prin urmare, problema relaţiei dintre fotosinteză şi respiraţie este cu mult peste cadrul unei simple comparări a funcţiilor de sinteză şi descompunere a compuşilor organici ai unei plante. Echivalentul energetic şi produsele intermediare sunt utilizate în procesele legate de formarea biomasei vegetale şi menţinerea integrităţii sale structurale şi funcţionale.

Monitorizarea proceselor fiziologice la plantele de păr și a factorilor ecologici sub forma de filmfitodiagramă în regim automat, prealabil, a fost publicată în revista Scientific Papers Series Management, Economic Engineering in Agriculture and Rural Development, 2020,v.20, issue 3, p.563-570.

\section{Concluzii}

A fost monitorizată curba de saturaţie a luminii pentru fotosinteză. A fost folosit fitomonitorul modern RTM-48A, care a permis măsurarea indicilor sub forma de film-fitodiagramă ce permite diagnosticarea proprietăților genotipului și a stării fiziologice a plantelor de păr. Curba de saturație a luminii pentru fotosinteza la plantele de păr a fost determinată ca urmare a evaluării intensității fotosintezei, respiraţiei, transpiraţiei, conductivităţii stomatelor în funcție de temperatură, umiditate și conţinutul de $\mathrm{CO}_{2}$ din aer. S-a stabilit valoarea minimă a luminii la care este iniţiat procesul de fotosinteză la plantele. Odată cu creșterea intensității luminii (1/3 din lumina totală) intensitatea fotosintezei crește după ce a avut loc optimizarea esențială a procesului. Respiraţia, transpiraţia și conductivitatea stomatelor confirmă curbele de saturație a luminii pentru fotosinteză la plantele de păr.

Cercetările au fost realizate în cadrul proiectului Programului de Stat 20.80009.5107.18 "Formarea direcționată a calității și sistemului imunitar la fructele soiurilor tardive de prun preconizate păstrării de lungă durată”, finanțat de Agenția Națională pentru Cercetare și Dezvoltare.

\section{Bibliografie}

1. ŞIŞCANU, Gh. Fotosinteza şi funcţionalitatea sistemului donator-acceptor la plantele pomicole. Chişinău, 2018. 316 p.

2. КАРМАНОВ, В. Г. Приложение автоматики и кибернетики к растениеводству. // ДАН СССР. 1959,т. 128, № 1.

3. ЛЯЛИН, О. О., РАДЧЕНКО, С.С., КАРМАНОВ, В. Г. Проблемы фитомониторинга на современном этапе. //Физические методы и средства получения информации в агромониторинге. Л-д, 1987, с.30-35.

4. ЛЯЛИН, О. О. Транспортные функции корня интактного растения. // Физиология растений. 1993, т. 40, вып.5, с. 811-820.

5. КЛЕЙМАН, Э. Bio Instruments S.R.L., г. Кишинев, Молдова.

6. БАЛАУР, Н.С., ВОРОНЦОВ, В.А., КЛЕЙМАН, Э.И., ТОН, Ю.Д. Новая технология мониторинга $\mathrm{CO}_{2}-$ обмена у растений // Физиология растений. 2009, т. 56. № 3, с. 486 - 470. 